Modern Cardiac Surgery 


\section{Modern Cardiac Surgery}

Based on the Proceedings of the Eighth Annual Course on Cardiac Surgery, organised by the British Postgraduate Medical Federation

Edited by

D. B. Longmore

Consultant Clinical Physiologist, The National Heart Hospital, London 
Published by

MTP Press Limited

Falcon House

Lancaster

England

Copyright (C) 1978 MTP Press Limited

Softcover reprint of the hardcover 1st edition 1978

All rights reserved. No part of this publication may be reproduced, stored in a retrieval system, or transmitted in any form or by any means, electronic, mechanical, photocopying, recording or otherwise, without prior permission from the publishers.

ISBN-13: 978-94-011-6202-9 e-ISBN-13: 978-94-011-6200-5

DOI: $10.1007 / 978-94-011-6200-5$ 


\section{Contents}

List of Contributors $\quad \mathrm{x}$

Foreword xiii

SECTION I INVITED LECTURES

The National Heart Hospital Surgical Lecture 'Transplantation of the heart'

E. B. Stinson and N. E. Shumway

The Hammersmith Cardiac Surgery. Lecture 'Tissue valve grafting'. Aortic valve replacement with autologous fascia lata

Å. Senning

SECTION II THE MITRAL VALVE

1. Echocardiography

T. A. Traill

2. Mitral valve disease: the case for cardiac catheterization

Celia M. Oakley

3. Closed mitral valvotomy

W. P. Cleland

4. Open mitral valvotomy

S. C. Lennox

5. Reconstruction of the mitral valve

M. Paneth

D. E. M. Taylor

7. Aortic homograft valves for mitral valve replacement

M. Yacoub

8. Echocardiographic studies after mitral valve replacement

D. G. Gibson 


\section{MODERN CARDIAC SURGERY}

9. Haemolysis associated with prosthetic valves-cardiac haemolytic anaemia, red cell fragmentation syndrome

D. A. Watson and S. M. Manohitharajah

10. Thromboembolism and valve failure: a multi-centre valve study R. J. Donnelly

11. Mitral valve replacement E. B. Stinson

12. Antimicrobial treatment of allograft valves W. H. Wain

SECTION III ENDOCARDIAL CUSHION

13. Anatomy of the common atrioventricular canal

F. E. de Salamanca, M. Ugarte and M. Quero

14. Conducting tissue in complete atrioventricular canal malformations

J. L. Wilkinson, Audrey Smith and R. H. Anderson

15. Atrioventricular canal: surgical anatomy and repair

C. Lincoln

16. Correction of complete atrioventricular canal in infancy

J. Stark

17. The results of repair of complete atrioventricular canal (a British multi-centre study)

D. K. C. Cooper

18. Anatomy and conducting tissue in partial atrioventricular canal defects

J. L. Wilkinson, Audrey Smith and R. H. Anderson

19. Surgery for ostium primum atrial septal defect

J. K. Ross

20. Endocardial cushion: partial A-V canal-long-term results

Å. Senning

SECTION IV SURGERY OF THE 4TH AND 6TH AORTIC CANAL

21. Results of patent ductus arteriosus ligation in infants and children R. J. Szarnicki

22. Vascular rings

M. R. de Leval and L. H. Burr

23. Surgical relief of coarctation of the aorta in infancy using the left sub-clavian arterial flap technique

B. I. Hamilton 


\section{CONTENTS}

24. Patent ductus arteriosus: indications, operative techniques and postoperative care in infants

C. Lincoln

25. Recoarctation of the aorta

J. P. Byrne and L. H. Burr

26. Coarctation of the aorta in the adult

W. P. Cleland

SECTION $V$ PULMONARY ATRESIA

27. The development of the pulmonary circulation in pulmonary atresia

Sheila G. Haworth

28. Surgical management of pulmonary atresia with confluent pulmonary arteries

J. P. Byrne

29. Pulmonary atresia with non-confluent pulmonary arteries

201

R. J. Szarnicki and M. R. de Leval

SECTION VI PALLIATIVE SURGERY FOR CYANOTIC HEART DISEASE IN INFANCY

30. The development of palliative operations for the tetralogy of Fallot

Lord Brock

31. Tetralogy of Fallot: haemodynamic and angiocardiographic considerations

F. J. Macartney

32. Late results of aortopulmonary shunts

S. C. Lennox

33. Palliative surgery for cyanotic heart disease in infancy

J. C. Lincoln

34. Open infundibulectomy in Fallot's tetralogy and hypoplastic pulmonary arteries

H. Oelert

35. Anatomical correction of complete transposition of the great arteries in infancy

M. Yacoub

SECTION VII LEFT VENTRICULAR FUNCTION AND PROTECTION

36. Non-invasive study of left ventricular function

D. G. Gibson 


\section{MODERN CARDIAC SURGERY}

37. Factors affecting left ventricular performance

Winifred G. Nayler and A. M. Slade

38. Elective cardiac arrest: historical perspective

D. G. Melrose

39. The role of electrolyte and temperature changes in myocardial protection

D. J. Hearse

40. Cold cardioplegia versus continuous coronary perfusion: clinical and cytochemical assessment

M. V. Braimbridge, D. J. Hearse, J. Chayen, L. Bitensky and

S. Ćanković-Darracott

41. Low sodium-induced arrest in patients

I. H. Rygg and G. Petersen

42. Myocardial preservation during extended periods of ischaemia. Experimental results with a new cardioplegic solution ('Sbokos 3' solution)

C. G. Sbokos

43. Intraoperative protection of the heart: topical myocardial hypothermia

E. B. Stinson

\section{SECTION VIII TRANSPOSITION OF THE GREAT ARTERIES}

44. The Mustard operation

J. P. Byrne

45. A current technique for the Mustard operation

J. Stark

46. Long-term results of the Mustard operation

J. F. N. Taylor and J. Stark

47. Reoperation for complications of the Mustard operation: technical considerations

R. J. Szarnicki

48. Management of transposition of the great arteries with left ventricular outflow tract obstruction

R. J. Szarnicki

49. Rastelli operation

M. R. de Leval

50. Atrial inversion for transposition of the great arteries using an intra-atrial dacron baffle: surgical technique and results

H. Oelert 


\section{CONTENTS}

51. Transposition of the great arteries

$$
\text { J. F. N. Taylor }
$$

52. Diagnosis of double outlet right ventricle (DORV) by M-mode echocardiography

D. G. Gibson

53. Arrhythmias after the Mustard operation: a study of 24-h tape monitoring

M. Tynan, D. S. Reid and A. Goodwin

SECTION IX COMPLICATED ATRIOSEPTAL DEFECTS

54. Complicated atrioseptal defects

Compiled by Sally P. Allwork

Index 


\section{List of Contributors}

\section{SALLY P. ALLWORK}

Hammersmith Hospital, London W12 0HS

\section{R. H. ANDERSON}

Royal Liverpool Children's Hospital, Myrtle Street, Liverpool 7

\section{BITENSKY}

Division of Cellular Biology,

The Mathilda and Terence Kennedy

Institute of Rheumatology

Bute Gardens, London W6 7DW

M. V. BRAIMBRIDGE

St Thomas's Hospital,

Lambeth Palace Road,

London SE1 7EH

\section{LORD BROCK}

Brompton Hospital,

Fulham Road,

London SW3 6HP

\section{H. BURR}

Thoracic Unit,

Hospital for Sick Children,

Gt Ormond Street,

London WC1N 3JH

\section{J. P. BYRNE}

Thoracic Unit,

Hospital for Sick Children,

Gt Ormond Street,

London WC1N 3JH

\section{S. ĆANKOVIĆ-DARRACOTT}

Department of Cardiothoracic Surgery,

St Thomas's Hospital,

Lambeth Palace Road,

London SE1 7EH

\section{J. CHAYEN}

Division of Cellular Biology,

The Mathilda and Terence Kennedy

Institute of Rheumatology,

Bute Gardens,

London W6 7DW

W. P. CLELAND

Department of Surgery,

Cardiothoracic Institute,

Brompton Hospital,

Fulham Road,

London SW3 6HP

D. K. C. COOPER

Thoracic Unit, Hospital for Sick Children,

Gt Ormond Street,

London WC1N 3JH

\section{R. J. DONNELLY}

Broadgreen Hospital, Thomas Drive,

Liverpool 14

\section{G. GIBSON}

Brompton Hospital, Fulham Road,

London SW3 6HP

\section{A. GOODWIN}

Department of Cardiology,

Newcastle General Hospital,

Newcastle-upon-Tyne

\section{I. HAMILTON}

Royal Liverpool Children's Hospital, Myrtle Street, Liverpool 7

\section{SHEILA G. HAWORTH}

Hospital for Sick Children,

Gt Ormond Street,

London WC1N 3JH 


\section{LIST OF CONTRIBUTORS}

D. J. HEARSE

The Myocardial Metabolism Research Laboratories,

Rayne Institute,

St Thomas's Hospital,

Lambeth Palace Road,

London SEl IEH

\section{S. C. LENNOX}

Brompton Hospital,

Fulham Road,

London SW3 6HP

\section{R. de LEVAL}

Thoracic Unit,

Hospital for Sick Children,

Gt Ormond Street,

London WCIN $3 \mathrm{JH}$

C. LINCOLN

Brompton Hospital,

Fulham Road,

London SW3 6HP

\section{F. J. MACARTNEY}

Institute of Child Health,

Guildford Street

London WCIN $3 \mathrm{JH}$

\section{S. M. MANOHITHARAJAH}

Leeds Regional Thoracic Surgical Centre,

Killingbeck Hospital,

Leeds 14

\section{G. MELROSE}

Royal Postgraduate Medical School,

Hammersmith Hospital,

Du Cane Road.

London W12 0HS

WINIFRED G. NAYLER

Cardiothoracic Institute,

2 Beaumont St,

London W1N 2DX

CELIA M. OAKLEY

Royal Postgraduate Medical School,

Hammersmith Hospital,

Du Cane Road,

London W12 0HS

\section{H. OELERT}

Klinik für Thorax,

Herzurd Geffässchirurgie,

D-3000 Hanover, West Germany

\section{PANETH}

Brompton Hospital,

Fulham Road,

London SW3 6HP

\section{G. PETERSEN}

Rigshospitalet, Copenhagen, Denmark

M. QUERO

C. S. La Paz,

Madrid, Spain

\section{S. REID}

Freman Hospital,

High Heaton,

Newcastle-upon-Tyne NE7 7DN

\section{J. K. ROSS}

Western Hospital,

Oakley Road, Mill Brook,

Southampton $\mathrm{SO} 94 \mathrm{WQ}$

\section{H. RYGG}

Rigshospitalet,

Copenhagen, Denmark

F. E. de SALAMANCA

Ciudad Sonatorio Carlos Haya,

Malaga, Spain

\section{G. SBOKOS}

2nd Department of Surgery,

Athens University School of Medicine,

King Paul's Hospital,

Athens 609, Greece

\section{A. SENNING}

Surgical Clinic A.

University Hospital of Zurich,

CH-8091, Zurich, Switzerland

\section{N. E. SHUMWAY}

Department of Cardiovascular Surgery, Stanford University,

Stanford, California 94305, USA

\section{A. M. SLADE \\ Cardiothoracic Institute \\ 2 Beaumont St, \\ London W1N 2DX}

\section{AUDREY SMITH}

Royal Liverpool Children's Hospital, Myrtle Street, Liverpool 7

\section{J. STARK}

Thoracic Unit,

Hospital for Sick Children,

Gt. Ormond Street,

London WCIN 3JH

\section{E. B. STINSON}

Department of Cardiovascular Surgery, Stanford University

Stanford, California 94305, USA 


\section{MODERN CARDIAC SURGERY}

R. J. SZARNICKI

Thoracic Unit,

Hospital for Sick Children,

Gt Ormond Street,

London WCIN 3JH

\section{E. M. TAYLOR}

Department of Applied Physiology and Surgical Sciences,

Royal College of Surgeons,

London

\section{J. F. N. TAYLOR}

Thoracic Unit,

Hospital for Sick Children,

Gt Ormond Street,

London WC1N 3JH

T. A. TRAILL

Brompton Hospital,

Fulham Road,

London SW3 6HP
M. TYNAN

Evelina Children's Department,

Guy's Hospital,

London SE1

M. UGARTE

Clinica Puerta de Hierro,

Madrid, Spain

W. H. WAIN

Brompton Hospital,

Fulham Road,

London SW3 6HP

\section{A. WATSON}

Leeds Regional Thoracic Surgical Centre, Killingbeck Hospital,

Leeds 14

\section{J. L. WILKINSON}

Royal Liverpool Children's Hospital, Myrtle Street, Liverpool 7

M. YACOUB

The National Heart Hospital,

Westmoreland Street,

London W1M 8BA 


\section{Foreword}

Modern Cardiac Surgery is based on, but does not consist completely of, papers submitted at the annual course of cardiac surgery run by the combined Institutes and Post-Graduate Hospitals involved in cardiac surgery in London (1977). The subjects which have been chosen and included fulfil one of two criteria; either they are subjects which were not included in the previous book, The Current Status of Cardiac Surgery, or they cover subjects which needed to be updated.

Because this is a teaching course and not a symposium, the emphasis has been on being informative rather than on presenting masses of results. The book has been prepared partly from manuscripts submitted by the authors and partly from annotated tapes of the proceedings of the meeting. Throughout the editing and production of this book careful consideration has been given to the requirements of the readership.

The book is aimed at all students of cardiac surgery and cardiology at all levels, and as much information as possible has been packed into it. Nevertheless, the editor wishes to thank the authors for the efforts they have made to be concise and clear in their presentation and for their tremendous co-operation in alterations which have been incorporated to make it a more readable treatise. This means that this is a book which is of value to nurses interested in cardiology in intensive care, to physiotherapists and students wishing to look up particular topics before their final examinations.

The work includes a variety of authors, representing several continents and many important cardiac surgical centres, who together represent experience from many thousands of patients, and a wide range of cardiac surgical procedures ranging from the simplest through to cardiac transplantation. Since the book is based on a teaching programme, where results are presented they represent the bare facts without the optimism which is sometimes shown at surgical meetings.

The courses which have formed the basis for The Current Status of Cardiac Surgery and Modern Cardiac Surgery really exist because of the efforts and vision of Mr William Paton Cleland, and the course which formed the basis for this book was the last one organized under his chairmanship. He retires from the National Health Service this year. He qualified MB, BS (second place on the honours list), from Adelaide University in 1934 at the age of 21. His father, Sir John Cleland, was Professor of Pathology at the University of 


\section{MODERN CARDIAC SURGERY}

Adelaide and was a most distinguished scientist. Bill Cleland and all his fou sisters have had distinguished academic careers. After a severe attack of pneumonia he became a chest physician in 1936 and became a member of the Royal College of Physicians at that time. During World War 2 he became a thoracic surgeon under Sir Clement Price Thomas, and then became a fellow of the Royal College of Surgeons after the war. During his appointment at the Hammersmith Hospital he was associated with the group who pioneered the heart/lung machine and cardiac surgery in Europe. It is because of this broad base that courses organized by Bill Cleland have been so comprehensive and that it has been possible to publish two books covering whole subjects in considerable detail from the basis of just two courses and a modest number of extra contributions.

The Editor wishes to thank all his colleagues who have contributed to this book, particularly for their forbearance in being asked to make many additions and alterations to their original contribution. He also wishes to thank Merilyn Smith and Marie Alcorn for handling all the correspondence and manuscript-checking in their spare time. He also wishes to thank the publishers for their help and advice.

D. B. Longmore 